\title{
PANCREATIC FUNCTION AND DISEASE IN EARLY LIFE. I. PANCREATIC ENZYME ACTIVITY AND THE CELIAC SYNDROME ${ }^{1}$
}

\author{
By SIDNEY FARBER, HARRY SHWACHMAN, AND CHARLOTTE L. MADDOCK \\ (From The Children's Hospital, The Infants' Hospital, and the Department of Pathology, \\ Harvard Medical School, Boston)
}

(Received for publication April 20, 1943)

The clinical features of idiopathic celiac disease include characteristic wasting, more in the limbs than in the face; distension of the abdomen, which may be soft, doughy, and inelastic, or markedly distended and tight; bulky, foul-smelling, frothy stools which contain excess fat; and, often, retardation of growth. To these findings may be added clumping of barium in the small intestine, a flat glucose tolerance curve, and a low rise in the vitamin $\mathrm{A}$ in the blood during the vitamin $\mathrm{A}$ absorption test (1). It is now recognized that these clinical and laboratory findings are encountered not only in idiopathic celiac disease but that many, if not all, may appear also as a result of, or in association with, congenital malformations of the small intestine and particularly of its mesenteric attachment, chronic infections such as tuberculosis of the peritoneal cavity, obstruction to the lacteals, megacolon, and a number of other disease states. This series of conditions, unrelated etiologically but capable of producing a common clinical picture, have been brought together in recent years under the term celiac syndrome.

In one group of patients suffering from a disease which for a long time was confused with idiopathic celiac disease, there has been found at autopsy a diffuse obstructive lesion in the pancreatic acini and ducts, accompanied often by parenchymal atrophy, dilatation of ducts, and fibrosis (2). No designation has been suggested which describes satisfactorily the clinical and pathologic characteristics of this disease, although many terms, among them cystic fibrosis of the pancreas (2), have been employed. This problem will be discussed elsewhere. For temporary convenience, until a more suitable term is found, this lesion will be referred to as "pancreatic fibrosis." Patients with this pancreatic lesion need not present the clinical features of the celiac syn-

1 These studies were supported by the Ann Proctor Rice Fund of Harvard Medical School. drome, and, indeed, the majority fail to do so. More frequently, the picture is one of a non-specific chronic nutritional disutrbance, complicated usually by symptoms of upper respiratory obstruction and infection. When patients with pancreatic fibrosis do have the clinical picture of the celiac syndrome, experience has shown that differentiation from idiopathic celiac disease on clinical grounds alone usually is impossible until after a prolonged period of observation or until improvement under treatment, which includes any one of the well-known celiac diets, makes it apparent that the condition is idiopathic celiac disease.

The obstructive nature of the lesion in the pancreas as seen histologically suggested that an important reduction in the amount of pancreatic juice, and perhaps in the formation of pancreatic enzymes, must obtain. It seemed likely that this pancreatic achylia or hypochylia was the explanation for much of the symptomatology of the disease. Actual determination of the pancreatic enzyme activity in the duodenal juice of such patients showed that marked reduction was indeed present ( 2 to 5 ). In a detailed report of pancreatic enzyme studies in the celiac syndrome (4), which supported her earlier observations (2), Dorothy Andersen included data on pancreatic enzyme activity in the duodenal content of 15 patients who had a clinical story consistent with pancreatic fibrosis. Postmortem verification of the diagnosis was obtained in $\mathbf{5}$ instances. Andersen found that the assay of trypsin is a reliable means of diagnosing pancreatic deficiency since the tryptic activity was uniformly low or absent in all patients with pancreatic fibrosis studied by her and present in normal amounts in the duodenal juice of patients with the other varieties of the celiac syndrome and of normal infants. Farber and Maddock presented a preliminary survey of their studies on pancreatic enzyme activity in $\mathbf{5 0}$ infants and children (3). In 4 patients who ex- 
hibited many of the clinical and laboratory features of the celiac syndrome, pancreatic enzyme activity in the duodenal content was greatly reduced or was absent, and in these patients, at postmortem examination, important obstructive changes in the duct-acinar system and variable degrees of fibrosis of the pancreas were found. Results of the analyses on these 4 patients were compared with the very much greater pancreatic enzyme activity observed in patients with idiopathic celiac disease and in a selected group of infants and children who showed none of the features of the celiac syndrome.

The purpose of this paper is to document and extend the conclusions given in the preliminary report by Farber and Maddock with data from more than 150 determinations of pancreatic enzyme activity in infants and children. To permit evaluation of the methods used and to gather data of possible value in increasing our understanding of disturbances of nutrition in infancy and childhood, enzyme determinations were made also, as occasion permitted, on the duodenal juice obtained from normal infants and children, patients suffering from various types of nutritional disturbances including idiopathic celiac disease, and, finally, from patients suffering from a miscellaneous group of disorders and concerning whose pancreatic function it was thought worthwhile to learn more. The normal infants varied in age from 1 week to 5 months, and the normal children from 5 to 10 years (Table I). The studies of Andersen (4) contain data from normal in- fants and children in the age periods lacking here. The generalizations offered from the present data are in agreement with those of Andersen.

The patients placed in the group called chronic nutritional disturbance presented a variety of complaints, the most common of which was a failure to gain in weight. There were 46 patients in this group, ranging in age from a few weeks to 7 years (Table II). When first seen, many gave histories of digestive disturbances, such as chronic diarrhea, intolerance to certain foods, anorexia, and occasional vomiting. Evidence of infection as a contributory cause was often present, and for this reason, those patients presenting the celiac syndrome secondary to infection are included in this group. In a few instances, the clinical appraisal of the patient left uncertain the exact cause of the underlying nutritional disturbance, particularly since infants with pancreatic achylia were removed from this group whenever proof was obtained by actual pancreatic enzyme analysis. In addition, there are included in this group 2 infants who, on admission to the hospital, were thought to have intestinal obstruction. One recovered without operation and the other required surgical correction. Only 1 patient in this entire group died, and postmortem examination revealed no evidence of disease of the pancreas.

Patients classified in the group idiopathic celiac disease showed a typical clinical picture and laboratory findings as described above. The therapeutic response to the well-recognized dietary management of true celiac disease was satisfactory

TABLE I

Normal infants and children

\begin{tabular}{|c|c|c|c|c|c|c|c|c|c|c|}
\hline Patient & Age & Sex & Weight & $\begin{array}{c}\text { Volume } \\
\text { of } \\
\text { fluid }\end{array}$ & \multicolumn{2}{|c|}{ Trypsin units } & \multicolumn{2}{|c|}{ Amylase units } & \multicolumn{2}{|c|}{ Lipase units } \\
\hline $\begin{array}{l}\text { P. F. } \\
\text { F. M.* } \\
\text { R. L.* } \\
\text { R. A. } \\
\text { R. H. } \\
\text { P. } \\
\text { J. T. } \\
\text { A. B. } \\
\text { R. P. } \\
\text { H. M. } \\
\text { E. C. }\end{array}$ & $\begin{array}{l}1 \text { week } \\
2 \text { weeks } \\
2 \text { weeks } \\
7 \text { weeks } \\
1 \text { month } \\
1 \text { month } \\
6 \text { weeks } \\
4 \text { months } \\
5 \text { months } \\
5 \text { 4/12 years } \\
67 / 12 \text { years } \\
108 / 12 \text { years }\end{array}$ & $\begin{array}{l}\mathbf{M} \\
\mathbf{M} \\
\mathbf{M} \\
\mathbf{F} \\
\mathbf{M} \\
\mathbf{M} \\
\mathbf{F} \\
\mathbf{F} \\
\mathbf{M} \\
\mathbf{F} \\
\mathbf{F}\end{array}$ & $\begin{array}{r}\text { lbs.-os. } \\
6-10 \\
5-15 \\
8-12 \\
10-10 \\
6-10 \\
8-5 \\
7-5 \\
11-15 \\
11 \\
44 \\
83\end{array}$ & $\begin{array}{c}c c . \text { per hour } \\
3.6 \\
2.1 \\
0.9 \\
6.7 \\
4.7 \\
10.0 \\
7.0 \\
9.5 \\
10.0 \\
17.0 \\
45.0 \\
14.2\end{array}$ & $\begin{array}{l}\text { per cc. } \\
309 \\
133 \\
137 \\
165 \\
160 \\
202 \\
237 \\
227 \\
313 \\
430 \\
307 \\
194\end{array}$ & $\begin{array}{c}\text { per hour } \\
1110 \\
280 \\
128 \\
1105 \\
752 \\
2020 \\
1660 \\
2160 \\
3130 \\
7310 \\
13800 \\
2760\end{array}$ & $\begin{array}{r}\text { per cc. } \\
0 \\
10 \\
0 \\
0 \\
12 \\
141 \\
3 \\
24 \\
22 \\
206\end{array}$ & $\begin{array}{r}\text { per hour } \\
0 \\
21 \\
0 \\
0 \\
56 \\
1410 \\
21 \\
228 \\
220 \\
3500\end{array}$ & $\begin{array}{c}\text { per } 100 c c . \\
45 \\
29 \\
22 \\
50 \\
36 \\
40 \\
35 \\
74 \\
44 \\
102 \\
41 \\
86\end{array}$ & $\begin{array}{c}\text { per howr } \\
162 \\
62 \\
20 \\
335 \\
172 \\
402 \\
245 \\
703 \\
440 \\
2040 \\
1870 \\
1220\end{array}$ \\
\hline
\end{tabular}

* Youngest sibling of patient with proved pancreatic fibrosis. 
TABLE II

Chronic nutritional disturbance

\begin{tabular}{|c|c|c|c|c|c|c|}
\hline Period & Number of patients & Average age & Volume of fluid & Trypsin & Amylase & Lipase \\
\hline $\begin{array}{l}0 \text { to } 3 \text { months } \\
3 \text { to } 6 \text { months } \\
6 \text { months to } 1 \text { year } \\
1 \text { to } 2 \text { years } \\
2 \text { to } 7 \text { years }\end{array}$ & $\begin{array}{r}10 \\
10 \\
9 \\
9 \\
8\end{array}$ & $\begin{array}{l}10 \text { weeks } \\
5 \text { months } \\
8.4 \text { months } \\
18 \text { months } \\
44 / 12 \text { years }\end{array}$ & $\begin{array}{l}c c . \\
7.1 \\
9.3 \\
9.4 \\
14.6 \\
14.5\end{array}$ & $\begin{array}{c}\text { units per cc. } \\
242 \\
259 \\
250 \\
288 \\
264\end{array}$ & $\begin{array}{c}\text { units per cc. } \\
14 \\
17 \\
123 \\
223 \\
293\end{array}$ & $\begin{array}{c}\text { urits per } 100 c c . \\
44 \\
45 \\
43 \\
46 \\
32\end{array}$ \\
\hline
\end{tabular}

and this was hastened in most cases by the parenteral administration of crude liver and vitamin $B$ complex (6). There were 11 patients in this group and none of them died. They varied in age from 11 months to 33 months (Table III).

Pancreatic fibrosis. Thirty-four determinations were made on the duodenal juice of $22 \mathrm{pa}$ tients who suffered from some form of a nutritional disorder which, in certain instances, was characterized by all the usual clinical features of the celiac syndrome (Table IV). In the majority of the patients in this group, however, the features of the celiac syndrome were not apparent. Malnutrition, abnormal stools, and respiratory difficulty were the most striking disturbances observed on clinical examination. The correlation of the regular occurrence at autopsy of pancreatic fibrosis and intrinsic obstruction in patients with this clinical picture permitted, after a time, some degree of accuracy in the recognition of new instances of the disease, and in the prediction of the results of enzyme analysis and postmortem examination. Ten of the 22 patients in this group were under 1 year of age, and 18 were under 2 years of age. In 12 of these 22 patients, postmortem examination revealed an important degree of obstruction in the acinar-duct system, accompanied by variable degrees of fibrosis and atrophy of the organ. Eight of the remaining patients are still alive. Postmortem examinations were not performed on 2 of the patients who died. Samples of the duodenal drainage were obtained in 2 instances through the cooperation of the Buffalo Children's Hospital.

The youngest in this group, an infant of $3 \frac{1}{2}$ weeks of age, differed from all other patients because it was born with signs of intestinal obstruction, found at operation at 2 days of age to be part of the picture of meconium ileus. The duo- denal content of this patient was analyzed for tryptic activity 1 week before death and none was found. Postmortem examination disclosed an advanced degree of atrophy, duct obstruction, and fibrosis of the pancreas. The duodenal content was studied for tryptic activity because postmortem studies had indicated that pancreatic achylia must obtain in this disease, too, since the pancreatic lesion was identical with that in patients with "pancreatic fibrosis."

\section{METHODS}

The methods employed in these studies are similar to those used by Andersen (4). The method for trypsin was an adaptation of the Waksman and Davison technique (4). Amylase was determined in the same manner, the substrate being prepared according to a modification of the method of Thompson, Tennant, and Wies (4). Lipase was determined by the Willstaetter, Waldschmidt, and Leitz method (4). A detailed account and a critical evaluation of the methods used in the present studies is published elsewhere (7).

TABLE III

Celiac disease (idiopathic)

\begin{tabular}{|c|c|c|c|c|c|c|c|}
\hline Patient & Age & Sex & Weight & $\begin{array}{c}\text { Volume } \\
\text { of } \\
\text { fluid }\end{array}$ & Trypsin & $\underset{\text { ase }}{\text { Amyl- }}$ & Lipase \\
\hline \multirow{6}{*}{$\begin{array}{l}\text { C. P. } \\
\text { C. C. } \\
\text { D. N. } \\
\text { P. K. }\end{array}$} & months & & lbs.-oz. & $\begin{array}{l}c c . \\
\text { per }\end{array}$ & $\begin{array}{l}\text { units } \\
\text { per }\end{array}$ & $\begin{array}{l}\text { units } \\
\text { per }\end{array}$ & units \\
\hline & 11 & F & $13-13$ & 3 & 310 & 70 & 40 \\
\hline & 12 & F & $15-1$ & 11 & 331 & 63 & 76 \\
\hline & 14 & $\mathbf{M}$ & $13-3$ & 25 & 227 & 59 & 54 \\
\hline & $\begin{array}{l}17 \\
19\end{array}$ & $\mathbf{M}$ & $\begin{array}{l}19-6 \\
19-3\end{array}$ & & $\begin{array}{l}236 \\
217\end{array}$ & $\begin{array}{r}64 \\
184\end{array}$ & $\begin{array}{l}38 \\
60\end{array}$ \\
\hline & & & & & 248 & 336 & 46 \\
\hline M. B. & 19 & $\mathbf{F}$ & $14-10$ & 13 & 401 & 272 & 55 \\
\hline M. H. & 20 & F & 13 & 27 & 337 & 150 & 61 \\
\hline & 20 & & 13 & 25 & 386 & 273 & 55 \\
\hline E. A. & 20 & F & $15-10$ & $\begin{array}{l}10 \\
30\end{array}$ & 318 & 144 & 21 \\
\hline & 21 & $\mathbf{F}$ & $13-14$ & 39 & 340 & & 84 \\
\hline S. W. & 31 & F & $21-2$ & 50 & 325 & 57 & 47 \\
\hline N. DiL. & 32 & $\mathbf{M}$ & $26-12$ & 100 & 284 & 239 & 59 \\
\hline & 33 & $\mathbf{F}$ & $23-8$ & 4 & 363 & 160 & 72 \\
\hline
\end{tabular}


TABLE IV

Pancreatic fibrosis

\begin{tabular}{|c|c|c|c|c|c|c|c|c|c|c|c|}
\hline Patient & Age & Sex & Weight & Volume & Tryp & units & Amyl & e units & Lipas & units & Outcome \\
\hline $\begin{array}{l}\text { G. W. } \\
\text { L. C. } \\
\text { S. M. } \\
\text { H. E. } \\
\text { Buffalo } \\
\text { B. P. } \\
\text { M. D. } \\
\text { B. H. } \\
\text { R. McG. } \\
\text { P. L. } \\
\text { J. C. } \\
\text { M. H. } \\
\text { C. C. } \\
\text { W. H. }\end{array}$ & $\begin{array}{c}3 \frac{1}{2} \text { weeks } \\
2 \frac{1}{2} \text { months } \\
3 \text { months } \\
4 \frac{1}{2} \text { months } \\
5 \text { months } \\
5 \frac{1}{2} \text { months } \\
6 \text { months } \\
5 \text { months } \\
5 \frac{1}{2} \text { months } \\
9 \text { months } \\
11 \frac{1}{2} \text { months } \\
21 \text { months } \\
25 \text { months } \\
7 \text { months } \\
8 \text { months } \\
8 \text { months } \\
1 \text { year } \\
14 \text { months } \\
14 \text { months } \\
19 \text { months } \\
19 \text { months } \\
20 \text { months } \\
21 \text { months } \\
29 / 12 \text { years } \\
3 \text { 2/12 years } \\
4 \text { 0/12 years } \\
3 \text { 9/12 years } \\
78 / 12 \text { years } \\
79 / 12 \text { years } \\
710 / 12 \text { years } \\
81 / 12 \text { years } \\
90 / 12 \text { years } \\
96 / 12 \text { years }\end{array}$ & $\begin{array}{l}F \\
F \\
F \\
F \\
F \\
F \\
F \\
F \\
M \\
F \\
F \\
F \\
F \\
M\end{array}$ & $\begin{array}{l}\text { lbs.-os. } \\
5-8 \\
\\
8-8 \\
11-1 \\
\\
9-12 \\
8-6 \\
8-9 \\
10-9 \\
13-7 \\
17-7 \\
16-4 \\
8-7 \\
15-10 \\
10 \\
15 \\
14-14 \\
11-13 \\
19-11 \\
18 \\
16-4 \\
21-1 \\
23 \\
28 \\
23-12 \\
42-12 \\
38-3 \\
41\end{array}$ & $\begin{array}{c}\text { cc. per hour } \\
0.3 \\
2.5 \\
1.0 \\
8.0 \\
3.0 \\
4.0 \\
15 \\
5 \\
3.8 \\
4.5 \\
4.1 \\
5.3 \\
1.5 \\
.5 \\
4.8 \\
3.0 \\
4.2 \\
1.1 \\
3 \\
2 \\
7 \\
3.5 \\
2.5 \\
2.2 \\
8.7 \\
2 \\
4.9 \\
10 \\
7 \\
\end{array}$ & $\begin{array}{l}\text { per cc. } \\
0 \\
9.0 \\
0 \\
0 \\
0 \\
0.5 \\
0.8 \\
1.8 \\
1.0 \\
9.6 \\
13.6 \\
10.2 \\
3.8 \\
0 \\
26.6 \\
0.2 \\
0 \\
0 \\
10.8 \\
8.4 \\
1.3 \\
0.4 \\
0 \\
0 \\
1.8 \\
0.8 \\
2.0 \\
0 \\
0.9 \\
0.7 \\
0 \\
0.3 \\
0.5\end{array}$ & $\begin{array}{c}\text { per hour } \\
0 \\
22.5 \\
0 \\
0 \\
0 \\
2.0 \\
12 \\
9.0 \\
3.8 \\
43.2 \\
55.7 \\
54.0 \\
5.7 \\
0 \\
128 \\
0.6 \\
0 \\
0 \\
32.2 \\
16.8 \\
9.1 \\
1.4 \\
0 \\
0 \\
15.7 \\
1.6 \\
9.8 \\
0 \\
6.3 \\
0 \\
4.2 \\
6.0\end{array}$ & $\begin{array}{c}\text { per } c c . \\
22.7 \\
2.5 \\
0 \\
1.6 \\
1.0 \\
18.2 \\
16.5 \\
\\
10.1 \\
68.0 \\
4.2 \\
18.8 \\
9.0 \\
18.2 \\
0.9 \\
78 \\
14.3 \\
0 \\
0 \\
4.9 \\
19.4 \\
30.0 \\
27.2 \\
30.4 \\
0 \\
19.7 \\
0.9 \\
1.6 \\
24 \\
0 \\
7.4 \\
0.8\end{array}$ & $\begin{array}{c}\text { per hour } \\
\\
56.7 \\
2.5 \\
0 \\
4.8 \\
4.0 \\
273 \\
82.5 \\
\\
45.5 \\
279.0 \\
22.3 \\
28.2 \\
4.5 \\
87.5 \\
2.7 \\
328 \\
15.7 \\
0 \\
0 \\
34.3 \\
68.0 \\
75.0 \\
60.0 \\
264 \\
0 \\
96.5 \\
9.0 \\
11.2 \\
\\
0 \\
104 \\
9.6\end{array}$ & \begin{tabular}{|c} 
per $100 c c$. \\
\\
5.1 \\
4.3 \\
0 \\
0.2 \\
0.2 \\
2.1 \\
2.6 \\
0.7 \\
12.9 \\
8.0 \\
3.2
\end{tabular} & $\begin{array}{c}26.4 \\
0 \\
6.7 \\
0 \\
6.9 \\
6.4 \\
0 \\
0 \\
1.3 \\
0 \\
0 \\
10.2 \\
5.4 \\
0 \\
0 \\
0 \\
0 \\
0 \\
7.2\end{array}$ & $\begin{array}{l}\text { D. P.M. } \\
\text { L. } \\
\text { D. P.M. } \\
\text { L. } \\
\text { D. P.M. } \\
\text { D. P.M. } \\
\text { D. P.M. } \\
\text { L. } \\
\text { D. P.M. } \\
\text { D. P.M. } \\
\text { L. } \\
\text { D. P.M. } \\
\text { D. P.M. } \\
\text { L. }\end{array}$ \\
\hline
\end{tabular}

\section{RESULTS}

On 4 of the accompanying figures, the data are arranged for comparison of the activity of trypsin, lipase, and amylase, and of the volume of the duodenal content of normal infants and children and of patients with chronic nutritional disturbances, idiopathic celiac disease, and pancreatic fibrosis. The statement may be made at once that the fluid obtained from the duodenum of patients with pancreatic fibrosis differs strikingly from that obtained from normal infants and children and from all other patients studied. These differences consist of smaller volume, altered viscosity, and a marked reduction, which amounts practically to disappearance, of tryptic, lipolytic, and amylolytic activity. The greatest amount of enzyme activity in patients with pancreatic fibrosis is so very much lower than the lowest range in all other patients studied that confusion in interpretation appears unlikely. It was stated earlier that an important obstructive lesion involving the acinar-duct system of the pancreas was demonstrated in every one of the 12 patients with pancreatic achylia who were examined after death. The occurrence of pancreatic achylia or hypochylia, therefore, is diagnostic of that form of the celiac syndrome and of the chronic nutritional disturbance accompanied by respiratory disease and associated with pancreatic fibrosis.

\section{Character and amount of fluid}

The contents of the duodenum of all patients, except those with pancreatic fibrosis, were non-viscous, clear, and varied in color from that of water to a pale lemon yellow, through deeper shades of yellow, depending on the bile content. The $\mathrm{pH}$ of the fluid fell within the range 6.5 to 9.0 The majority of fluids analyzed were between $\mathrm{pH} 7.5$ and 
8.0. The amount collected from the same individual over a given period (30 minutes to 1 hour) varied in the fasting state and with increasing age. In an infant under 2 months, the amount of fluid collected varied from 1 to $5 \mathrm{cc}$. per hour and was usually near $3 \mathrm{cc}$; in an infant of 1 year, this amount was doubled, and was often increased eightfold in older children. The amount of fluid obtained was apparently not affected appreciably by crying or excitement. The volume of the duodenal contents of normal children and of patients suffering from chronic nutritional disturbance, pancreatic fibrosis, and idiopathic celiac disease is changed according to age (Figure 1). In general, it was found that the volume of duodenal contents obtained from patients with idiopathic celiac disease was greater than that obtained from either normal children or those with chronic nutritional disturbance. The duodenal content of patients with pancreatic fibrosis was smaller in volume throughout all age groups than any other encountered in these studies. Although the quantitative collection of the duodenal content, under the conditions which obtained, permits only approximate estimations, rough differentiation could be made between fluid obtained from patients with pancreatic fibrosis and from patients with idiopathic celiac disease on the basis of the volume of the duodenal content alone.

The viscosity of the fluid obtained from normal children and from patients with idiopathic celiac disease or chronic nutritional disturbance varied little. The thick sticky material obtained from the duodenum of patients with pancreatic fibrosis was strikingly different from the thin watery contents obtained from all other individuals studied. The duodenal content from a patient with pancreatic fibrosis would adhere to the glass rod or to the side of the test tube and fall very slowly (Figure 2). The gross appearance of this material has its counterpart in the histologic appearance of inspissated material in the acini and ducts of the pancreas.

Trypsin. The values for tryptic activity, as determined in the several groups of patients studied, are arranged in Figure 3 . It is seen that the lowest value in any of the groups studied, except for those patients with pancreatic fibrosis, is in the neighborhood of 200 units. This may be compared with the values which hover around the zero

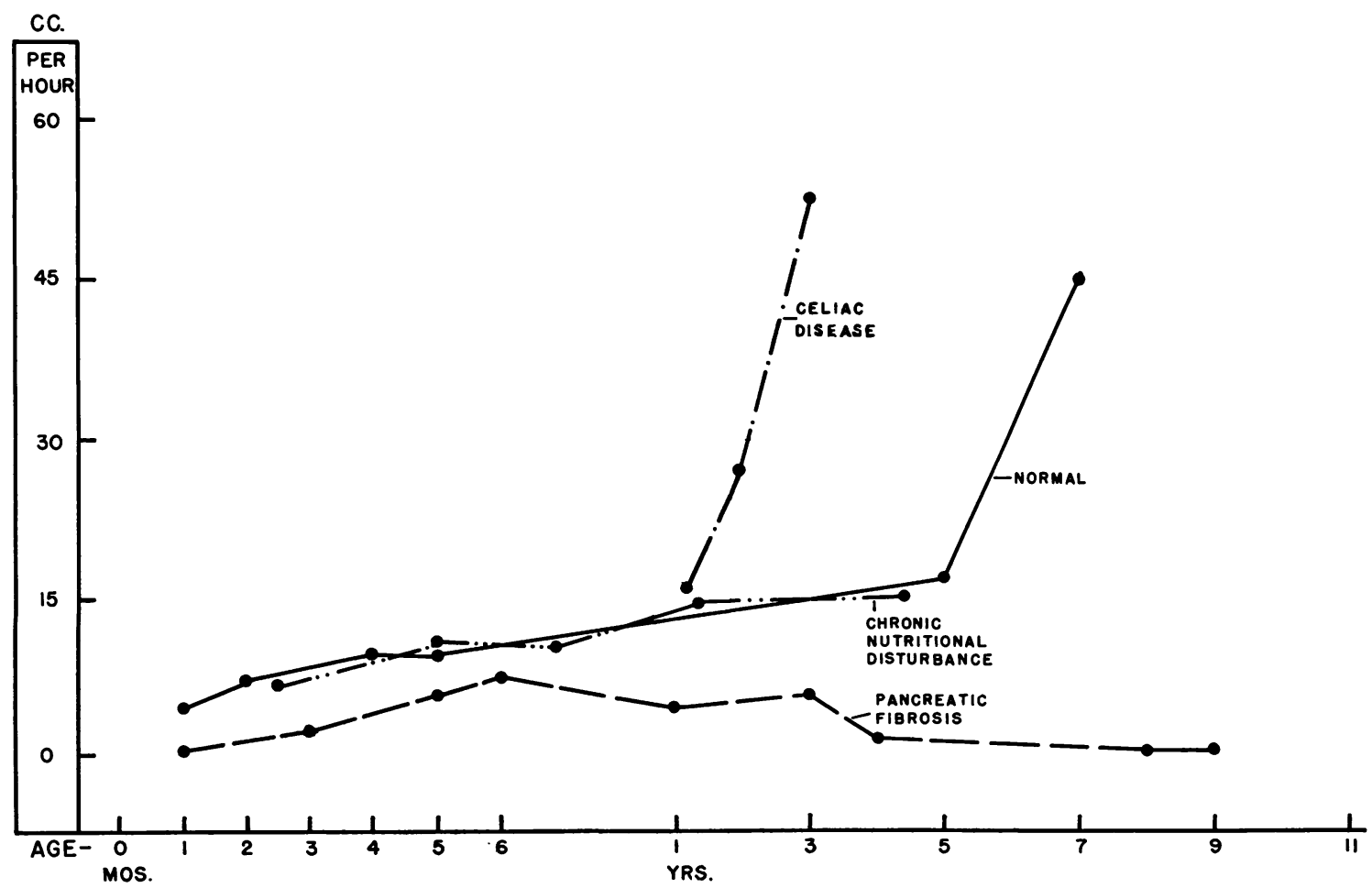

Fig. 1. Volume of Duodenal Contents 


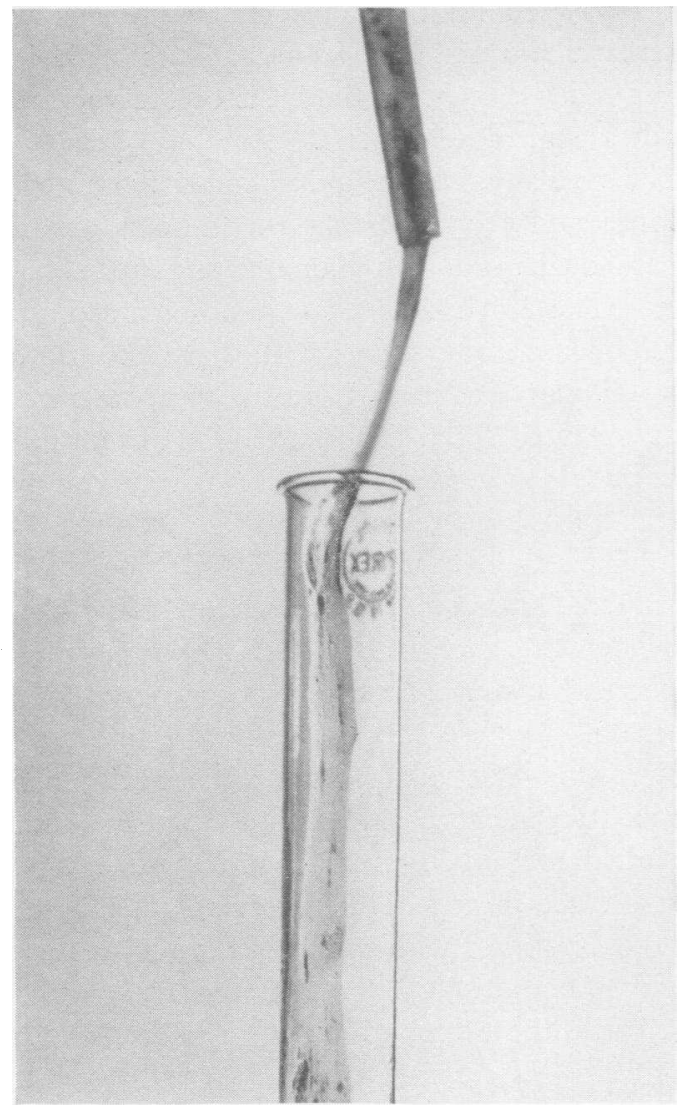

Fig. 2. Duodenal Content from Patient with Pancreatic Fibrosis

Note viscous, almost mucilaginous, character of the pancreatic juice which adheres to the pipette above and the test tube below.

mark in all of the patients with pancreatic fibrosis. The low values for tryptic activity alone may be used as a simple means of differentiation between pancreatic fibrosis and idiopathic celiac disease if insufficient fluid is obtained to permit the determination of lipolytic and amylolytic activity. Some degree of caution must be exercised, however, since in one instance, we have encountered absent tryptic activity in a patient who had normal amounts of lipase and amylase in his duodenal juice, a finding that has remained constant at subsequent determinations and after stimulation of secretion.

Lipase. The values for lipolytic activity in normal infants and children show wide variation, but here again no confusion is possible between the extremely low values for all patients with pan- creatic fibrosis and the very much higher values for all other patients studied (Figure 4). In 7 of over 150 determinations, low values which lay between 8.6 and 29.7 units were obtained. The duodenal fluid of these patients with low lipolytic activity contained normal concentrations of trypsin and amylase. Their clinical picture was one of chronic nutritional disturbance. This group will receive further investigation since the significance of these low lipase values is not apparent from these studies.

Amylase. The values for amylase are low in normal infants and children during the first 6 months. Confusion, therefore, would be possible if amylolytic activity alone were studied. In comparative studies on individuals older than 6 months, the extremely low amylolytic activity observed from birth in patients with pancreatic fibrosis stands out in contrast to the very much higher levels in normal individuals, in patients with idiopathic celiac disease, and chronic nutritional disturbances (Figure 5).

\section{Selected control series}

Advantage was taken of the opportunity to determine the pancreatic enzyme activity on a group of 24 selected infants and children who suffered from a number of different disorders, some of which it was thought, on pathologic or clinical grounds, might be associated with altered pancreatic function. The data so obtained served also as controls for the findings in pancreatic fibrosis. The data concerning pancreatic enzyme activity in the selected patients are summarized in Table V. In the brief discussion of the findings in this group that follows, numbers which appear in parentheses refer to the order in the table. Five patients with liver disease (Cases 1 to 5 ) were studied and all had enzyme activity within normal limits for their age, except as noted below. One, a patient of 5 weeks (Case 1), had obstruction to the common duct, caused by inspissation of bile, which was relieved at operation. Another (Case 2) suffered from toxic hepatitis as proved at autopsy. Severe icterus was present in this patient and also in an infant $4 \frac{1}{2}$ months of age (Case 5) who recovered from what was called infectious jaundice after an exploratory laparotomy. Two 


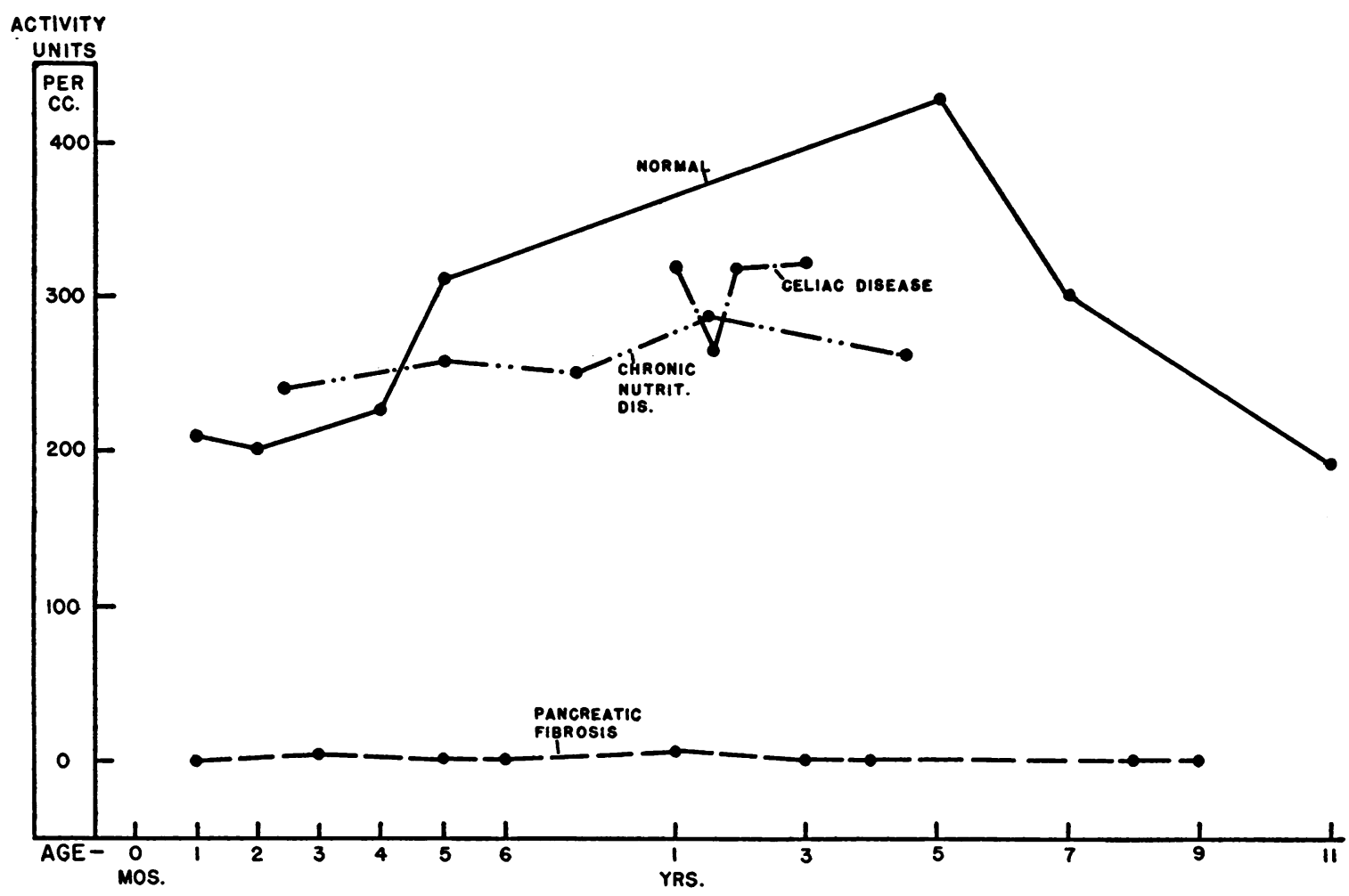

FIG. 3. TRYPSIN

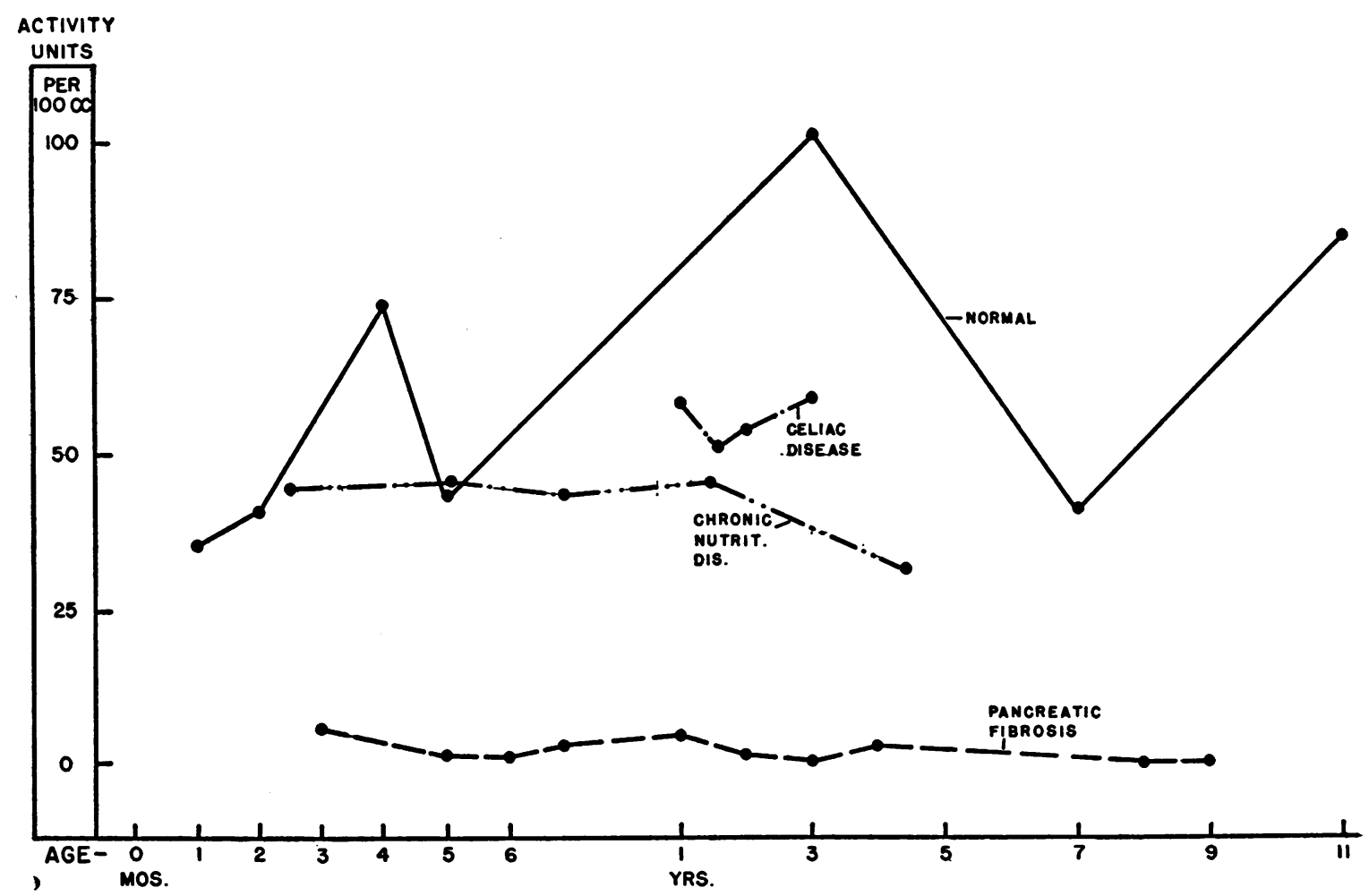

Fig. 4. LIPASE 


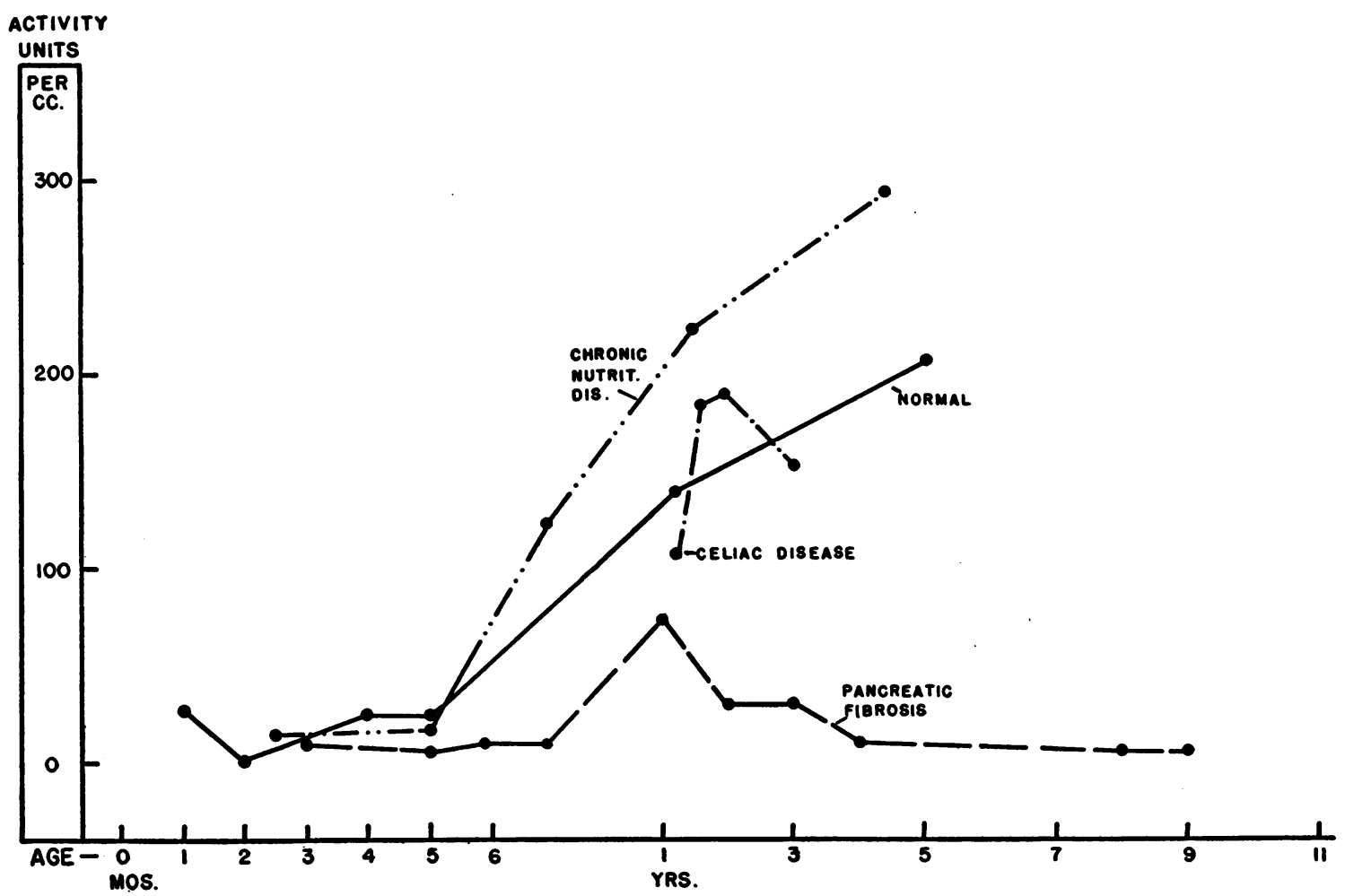

Fig. 5. Amylase

infants (Cases 3 and 4) had no bile in the duodenal fluid because of congenital atresia of the hepatic bile ducts. The amount of tryptic activity in both instances was low but was not so low as to be confused with the greatly reduced values which characterize pancreatic fibrosis. Lipolytic activity was somewhat reduced in 1 , and was well within the normal variation for the age.

The similarity of the cough in patients with pancreatic fibrosis to that observed in pertussis, and the occasional report of pancreatic fibrosis observed in patients who have had pertussis, made it of interest to examine the duodenal content of an infant who had just recovered from the acute phase of that disease (Case 6). The results were approximately normal for the age. Certain similarities in the type of breathing and in the pathological picture of patients with asthma and those with pancreatic fibrosis suggested the examination of the duodenal content of patients with asthma (Cases 13 to 15). Enzyme activity was well within normal limits in 3 patients with asthma, 2 of whom suffered, in addition, from eczema (Cases 13 and 14). No one of these patients, of course, was suffering from an acute attack of asthma at the time the determinations were made.

Normal values were found also in a patient with nephrosis (Case 16). Interference with the formation of pancreatic enzymes or obstruction to the outflow of pancreatic juice in patients with nephrosis is a theoretical possibility, since the pancreas in such patients becomes greatly increased in size and consistency as a consequence of the widespread edema of the organ. In an infant 13 months of age with congenital megaloureters, no abnormalities in pancreatic function were found (Case 9). The normal findings in 2 patients with cretinism (Cases 7 and 8) and 1 with dwarfism (18) confirm the clinical impression that the exocrine function of the pancreas is not altered in these conditions.

Four patients were of particular interest to the problem of celiac syndrome. In 1 of them, a girl of $121 / 2$ years of age with the clinical picture of non-tropical sprue, pancreatic enzyme activity was well within normal limits (Case 18). Two other children, both over 9 years of age, suffered from symptoms characteristic of the celiac syndrome, 
secondary to malrotation of the bowel (Cases 19 and 20). In neither case was an abnormality of pancreatic function demonstrable. The mother of one of our patients with idiopathic celiac disease herself suffered from what was called idiopathic steatorrhea (Case 21). She, too, showed normal pancreatic enzyme activity in her duodenal juice, which was obtained with the assistance of the Medical Service of the Peter Bent Brigham Hospital. The findings in these 4 patients do not differ from those in idiopathic celiac disease.

It was possible to examine the duodenal content of 3 patients who suffered from hypoglycemia with convulsions. In one instance, the rare opportunity was afforded to study the pancreatic enzyme activity 18 days before, and again 16 days after the operative removal of 4 grams (approximately 70 per cent) of the pancreas from a patient, 7 months of age (Case 10). There was a definite reduction in enzyme activity after the operation but sufficient activity was present to indicate an adequate amount of pancreatic function. In a second patient, 34 months of age, who suffered also from hypoglycemia and convulsions and whose nutritional state did not appear abnormal, the duodenal content was obtained 5 weeks after 11 grams, or approximately 80 per cent, of the pancreas had been removed at operation (Case 11). The level of tryptic activity was less than half the expected normal for the age of the patient, but was far above the pancreatic fibrosis range. Lipolytic activity, likewise, was decreased but amylolytic activity was elevated. The third patient with hypoglycemia and convulsions had essentially normal levels (Case 12).

It seemed desirable to obtain data concerning enzyme activity in the duodenal juice of prematurely born infants. The pancreas of the pre-

TABLE V

\begin{tabular}{|c|c|c|c|c|c|c|c|c|c|}
\hline$\underset{\text { ber }}{\text { Num- }}$ & Diagnosis & Patient & Age & Sex & Weight & $\begin{array}{l}\text { Volume } \\
\text { of fluid }\end{array}$ & $\underset{\text { units }}{\text { Trypsin }}$ & $\underset{\text { units }}{\text { Amylase }}$ & $\begin{array}{c}\text { Lipase } \\
\text { units }\end{array}$ \\
\hline 1 & $\begin{array}{l}\text { Common duct obstruction } \\
\text { due to inspissation of bile }\end{array}$ & B. A. & 5 weeks & $\mathbf{M}$ & $\begin{array}{r}\text { lbs.-os. } \\
8-10\end{array}$ & $\begin{array}{c}\text { cc. per hour } \\
3.3\end{array}$ & $\begin{array}{l}\text { per } c c . \\
128\end{array}$ & $\begin{array}{l}\text { per } c c . \\
24\end{array}$ & $\begin{array}{c}\text { per } 100 \mathrm{cc} . \\
6.6\end{array}$ \\
\hline 2 & Toxic hepatitis & A. D. & 7 weeks & $\mathbf{F}$ & $7-1$ & 7.1 & 100 & $\mathbf{0}$ & 9.8 \\
\hline $\begin{array}{l}3 \\
4\end{array}$ & $\begin{array}{l}\text { Congenital atresia of bile } \\
\text { ducts }\end{array}$ & $\begin{array}{l}\text { R. O'C. } \\
\text { F. L. }\end{array}$ & $\begin{array}{l}2 \text { months } \\
3 \text { months }\end{array}$ & $\begin{array}{l}\mathbf{M} \\
\mathbf{M}\end{array}$ & $\begin{array}{l}8-2 \\
6\end{array}$ & $\begin{array}{l}1.6 \\
3.6\end{array}$ & $\begin{array}{l}102 \\
107\end{array}$ & $\begin{array}{l}0 \\
7.7\end{array}$ & $\begin{array}{l}35 \\
17.9\end{array}$ \\
\hline 5 & Jaundice, infectious & R. F. & $4 \frac{1}{2}$ months & $\mathbf{M}$ & $7-15$ & 9.8 & 171 & 3.8 & 40.8 \\
\hline 6 & Pertussis & W. C. & $3 \frac{1}{2}$ months & $\mathbf{M}$ & $6-13$ & 6 & 283 & 0.3 & 28.1 \\
\hline $\begin{array}{l}7 \\
8\end{array}$ & Cretinism & $\begin{array}{l}\text { F. G. } \\
\text { P. G. }\end{array}$ & $\begin{array}{l}4 \frac{1}{2} \text { months } \\
21 \text { months }\end{array}$ & $\begin{array}{l}\mathbf{M} \\
\mathbf{F}\end{array}$ & $\begin{array}{l}10-10 \\
21-11\end{array}$ & $\begin{array}{l}2.1 \\
3.3\end{array}$ & $\begin{array}{l}154 \\
228\end{array}$ & 335 & $\begin{array}{l}25.7 \\
49.8\end{array}$ \\
\hline 9 & $\begin{array}{l}\text { Congenital malformation of } \\
\text { ureters }\end{array}$ & N. B. & 13 months & $\mathbf{M}$ & $10-15$ & 10 & 428 & 412 & 60 \\
\hline $\begin{array}{l}10 \\
11 \\
12\end{array}$ & $\begin{array}{l}\text { Hypoglycemia with } \\
\text { convulsions }\end{array}$ & $\begin{array}{l}\text { H. L. } \\
\text { B. L. } \\
\text { R. T. }\end{array}$ & $\begin{aligned} 7 & \text { months } \\
8 & \text { months } \\
34 & \text { months } \\
19 & \text { months }\end{aligned}$ & $\begin{array}{l}\mathbf{F} \\
\mathbf{F} \\
\mathbf{M}\end{array}$ & $\begin{array}{l}14-2 \\
23-8\end{array}$ & $\begin{array}{l}20 \\
8 \\
8.5\end{array}$ & $\begin{array}{r}290 \\
212 \\
98 \\
306\end{array}$ & $\begin{array}{r}96 \\
51 \\
308 \\
200\end{array}$ & $\begin{array}{l}70.3 \\
27.2 \\
8.8 \\
90\end{array}$ \\
\hline $\begin{array}{l}13 \\
14\end{array}$ & Asthma with eczema & $\begin{array}{l}\text { B. C. } \\
\text { F. G. }\end{array}$ & $\begin{array}{l}17 \text { months } \\
20 \text { months }\end{array}$ & $\begin{array}{l}\mathbf{M} \\
\mathbf{M}\end{array}$ & $\begin{array}{l}17-12 \\
24\end{array}$ & $\begin{array}{l}14 \\
18\end{array}$ & $\begin{array}{l}227 \\
229\end{array}$ & $\begin{array}{r}60 \\
110\end{array}$ & $\begin{array}{l}40 \\
38\end{array}$ \\
\hline 15 & Asthma & W. R. & 20 months & $\mathbf{M}$ & 23-12 & 8.8 & 579 & 532 & 40.6 \\
\hline 16 & Nephrosis & J. M. & $53 / 12$ years & $\mathbf{M}$ & $47-2$ & 61 & 475 & 325 & 65.6 \\
\hline 17 & Dwarfism & A. B. & $94 / 12$ years & $\mathbf{M}$ & $35-8$ & 25 & 203 & 140 & 70 \\
\hline 18 & Sprue & A. $\mathbf{P}$. & $126 / 12$ years & $\mathbf{F}$ & $59-4$ & 160 & 370 & 236 & 23 \\
\hline $\begin{array}{l}19 \\
20\end{array}$ & $\begin{array}{l}\text { Celiac syndrome associated } \\
\text { with malrotation of bowel }\end{array}$ & $\begin{array}{l}\text { R. B. } \\
\text { D. P. }\end{array}$ & $\begin{array}{l}96 / 12 \text { years } \\
92 / 12 \text { years }\end{array}$ & $\underset{\mathbf{F}}{\mathbf{M}}$ & $\begin{array}{l}46 \\
45-12\end{array}$ & & $\begin{array}{l}172 \\
301\end{array}$ & $\begin{array}{r}67 \\
341\end{array}$ & $\begin{array}{l}56 \\
73\end{array}$ \\
\hline 21 & Idiopathic steatorrhea & D. $\mathbf{R}$. & 36 years & $\mathbf{F}$ & & 165 & 217 & 143 & 50 \\
\hline
\end{tabular}


TABLE VI

Premature infants

\begin{tabular}{|c|c|c|c|c|c|c|c|c|c|c|}
\hline Patient & Age & Sex & Weight & Volume of fluid & \multicolumn{2}{|c|}{ Trypsin activity } & \multicolumn{2}{|c|}{ Amylase activity } & \multicolumn{2}{|c|}{ Lipase activity } \\
\hline $\begin{array}{l}\text { A. } \\
\text { S. } \\
\text { F. }\end{array}$ & $\begin{array}{l}2 \text { weeks } \\
7 \text { weeks } \\
3 \text { months }\end{array}$ & $\begin{array}{l}\mathbf{M} \\
\mathbf{M} \\
\mathbf{M}\end{array}$ & $\begin{array}{l}\text { lbs.-oz. } \\
4-14 \\
5-3 \\
5-15\end{array}$ & $\begin{array}{c}c c . \text { per hour } \\
2 \\
2.5 \\
1.4\end{array}$ & $\begin{array}{c}\text { per } c c . \\
180 \\
142 \\
231\end{array}$ & $\begin{array}{c}\text { per hour } \\
360 \\
355 \\
324\end{array}$ & $\begin{array}{c}\text { per } c c . \\
18 \\
0 \\
17\end{array}$ & $\begin{array}{c}\text { per hour } \\
36 \\
0 \\
24\end{array}$ & $\begin{array}{c}\text { per } 100 \mathrm{cc} \text {. } \\
18 \\
8 \\
40\end{array}$ & $\begin{array}{c}\text { per hour } \\
36 \\
20 \\
56\end{array}$ \\
\hline
\end{tabular}

mature baby has more connective tissue in proportion to the parenchyma than the pancreas of full-term or older infants. The smallest baby examined was somewhat less than 5 pounds in weight, so that data on very small babies were not obtained. It was possible to examine only 3 infants. The values for trypsin and lipase were within normal limits except for some reduction in the amount of lipase in 1 patient (Table VI). In that case, however, the amount was definitely greater than that found in pancreatic fibrosis. The small amounts of amylase in 2 infants, and the absence of amylase in a third infant, are consistent with the age of the patient and do not differ from the findings in full-term infants. If the data obtained from these premature babies are representative of what might be obtained in a larger series, and in smaller infants, it may be concluded that the pancreas of the prematurely born infant is capable of producing amounts of trypsin and lipase of the same order of magnitude as that of the full term baby and in amounts certainly adequate for the needs of the infant.

\section{DISCUSSION}

Pancreatic enzyme activity in the duodenal contents of infants and children has been studied by a number of observers. Since the basic work in 1912 of A. F. Hess (8), who determined the enzyme activity not only in normal infants and children but also in acute nutritional disturbances, marasmus, and certain febrile diseases, the studies of Davison (9), Klumpp and Neale (10), Andersen (4), and others, have yielded important data concerning pancreatic enzyme activity in early life. Klumpp and Neale studied a large series of infants and children and called attention to the low concentration of amylase during the first year of life. Isolated reports of the recognition of pancreatic deficiency by means of pan- creatic enzyme studies have been given by Benoit (11), Tiling (12), and by Siwe (13). Recently, pancreatic enzyme analysis in infants and children has assumed new importance in the differentiation of idiopathic celiac disease from pancreatic fibrosis $(4,3)$. The studies of Andersen have shown also that determination of the serum amylase was of no value in the diagnosis of congenital pancreatic deficiency (4).

It is evident that the symptom complex termed the celiac syndrome includes a number of different diseases, in addition to true celiac disease, the cause of which is still unknown. That true celiac disease is identical with sprue has been suggested by Hanes and McBryde (14). One form of the celiac syndrome is associated with pancreatic insufficiency, as is shown by the demonstration during life of a true hypochylia or achylia pancreatica and by the finding at autopsy of intrinsic obstruction to the outflow of pancreatic juice. Until recently, patients with this pancreatic disease have died almost invariably, whereas patients with idiopathic celiac disease respond well, if at times slowly, to dietary treatment of one kind or another. It is important, therefore, to have available a diagnostic method which will permit accurate differentiation of pancreatic disease from idiopathic celiac disease when the patient is seen for the first time and before the course of the disease and the response to dietary treatment will permit differentiation on clinical grounds alone. The striking features of the celiac syndrome, observed in some of the patients with pancreatic fibrosis, have obscured the fact that the majority of the patients in whom pancreatic achylia is produced by this pancreatic lesion do not exhibit a clinical picture which could be confused with idiopathic celiac disease. The explanation for this may be that death occurs before that particular form of malnutrition called the celiac syndrome 
can be achieved or, as is frequently the case, the symptoms of upper respiratory obstruction and distress are so striking that clinical findings referable to the gastro-intestinal tract, other than diarrhea or abnormal stools, are masked. The best method available for differentiating accurately between idiopathic celiac disease and that form of the celiac syndrome caused by pancreatic fibrosis is the determination of pancreatic enzyme activity in the duodenal content. The same diagnostic procedure permits recognition of pancreatic fibrosis when the features of the celiac syndrome either are not prominent or are not present. Whenever pancreatic achylia is demonstrated by such examination, it may be assumed that an important obstructive lesion in the pancreas is present.

These studies suggest the value of a temporary classification of all patients with chronic nutritional disturbance into two groups on the basis of pancreatic enzyme analysis alone : those with pancreatic achylia and those with normal pancreatic function. Further subdivision of those with normal pancreatic function may then be made on clinical grounds and with the aid of other laboratory procedures. Certainly no diagnosis of celiac syndrome, idiopathic steatorrhea, idiopathic celiac disease, non-tropical sprue, pancreatic fibrosis, or any of the other subdivisions of the celiac syndrome should be regarded as established until the levels of pancreatic enzyme activity in the duodenal content have been obtained. When this is done routinely, an accurate idea will be available for the first time of the true incidence of those diseases which are grouped under the term celiac syndrome.

Our experience has shown that pancreatic achylia in these patients is not a transient phenomenon and that it is unaffected by therapy. One patient, still alive, had greatly reduced pancreatic enzyme activity in her duodenal content on 6 determinations, the first of which was made when she was 5 months of age and the last when she was 25 months of age. The combination of general care, pancreatic substitution therapy, and replacement of nitrogen loss by the administration of casein hydrolysate (15) has served to prolong life, but has been without effect, apparently, on the pancreatic lesion. The nature of the pancreatic lesion responsible for pancreatic achylia and its relation to other disturbances in these patients are considered elsewhere (16).

The constant finding of markedly reduced or absent tryptic activity in all patients with pancreatic fibrosis suggests that analysis of the tryptic activity alone might be sufficient for an accurate diagnosis of pancreatic fibrosis. We have encountered only one exception to the observation that, when tryptic activity is greatly reduced, similar reduction is present also in amylolytic and lipolytic activity. That patient was a boy whose clinical picture was one of chronic nutritional disturbance and who was found to have reduction only in tryptic activity on repeated examination. A fairly accurate prediction of the results of enzyme analysis may be made in many instances of pancreatic fibrosis on the basis of the great viscosity and the small volume of the duodenal content. Even though analysis of the tryptic activity alone will lead only rarely to an incorrect interpretation, experience accumulated from studies of pancreatic function in infants and children is too small to permit short-cuts in technique. The present state of our knowledge of pancreatic function in early life necessitates more detailed and complex studies, rather than simplification of the methods already in use. Additional information, for example, obtained from stimulation of the vagal mechanism as well as of the humeral mechanism of pancreatic enzyme formation and liberation by the use of mecholyl chloride and secretin should add to our understanding of nutritional disorders in early life.

\section{SUMMARY AND CONCLUSIONS}

1. A report is given of the results of over 150 determinations of pancreatic enzyme activity and of the volume and character of the fluid in the duodenal content of infants and children, some of whom were normal individuals and others patients suffering from chronic nutritional disturbance, idiopathic celiac disease, and pancreatic fibrosis.

2. Pancreatic achylia is a constant and characteristic finding in patients in whom postmortem examination reveals important obstructive changes in the duct-acinar system of the pancreas (pancreatic fibrosis). Some of these patients have a clinical picture which may be confused with idiopathic celiac disease. The majority suffer from a 
chronic nutritional disturbance, complicated by upper respiratory disease.

3. Patients with idiopathic celiac disease, nontropical sprue, idiopathic steatorrhea, or that form of the celiac syndrome associated with malrotation of the bowel show no evidence of pancreatic achylia. In their duodenal content, pancreatic enzyme activity is well within the normal range and far greater than that observed in patients with pancreatic fibrosis.

4. The determination of pancreatic enzyme activity in the duodenal content permits accurate differentiation of that form of the celiac syndrome caused by pancreatic fibrosis from all other forms of the celiac syndrome, including idiopathic celiac disease, and furnishes a means of ascertaining the presence of pancreatic achylia and pancreatic fibrosis, in patients who suffer from malnutrition and upper respiratory disease, but who do not exhibit the clinical features of the clinical syndrome.

5. No diagnosis of idiopathic celiac disease, idiopathic steatorrhea, non-tropical sprue, pancreatic fibrosis, or other similar diseases should be considered established until the pancreatic enzyme activity of the duodenal drainage has been measured.

6. The persistence of pancreatic achylia, unchanged over a period of 20 months and unaffected by therapy, in an infant with pancreatic fibrosis has been demonstrated by 6 separate analyses of the duodenal content.

7. Selective trypsin deficiency is described in a boy with normal lipolytic and amylolytic activity.

8. The demonstration of pancreatic achylia and pancreatic fibrosis in an infant with meconium ileus is reported.

9. In infants with liver disease or with congenital exclusion of bile from the duodenum, essentially normal pancreatic enzyme activity was found. No abnormalities in pancreatic enzyme activity were found in 3 larger prematurely born babies and in infants and children suffering from asthma, eczema, pertussis, cretinism, or nephrosis.

10. Surgical removal of from 70 to 80 per cent of the pancreas of infants suffering from hypoglycemia and convulsions caused an appreciable reduction in enzyme activity but did not produce pancreatic insufficiency.

\section{BIBLIOGRAPHY}

1. May, C. D., and McCreary, J. F., The absorption of vitamin A in celiac disease. J. Pediat., 1941, 18, 200.

2. Andersen, D. H., Cystic fibrosis of the pancreas, vita$\min$ A deficiency, and bronchiectasis. J. Pediat., 1939, 15, 763.

3. Farber, S., and Maddock, C. L., The relation of the pancreas to the celiac syndrome. Am. J. Path., 1941, 17, 445.

4. Andersen, D. H., Pancreatic enzymes in the duodenal juice in the celiac syndrome. Am. J. Dis. Child., 1942, 63, 643.

5. Farber, S., and Maddock, C. L., Pancreatic disease and enzyme analysis in early life. Bull. New England M. Center, 1941, 3, 188.

6. May, C. D., McCreary, J. F., and Blackfan, K. D., Notes concerning the cause and treatment of celiac disease. J. Pediat., 1942, 21, 289.

7. Shwachman, H., Farber, S., and Maddock, C. L., Methods of analysis of pancreatic enzymes. Am. J. Dis. Child., In press.

8. Hess, A. F., The pancreatic ferments in infants. Am. J. Dis. Child., 1912, 4, 205.

9. Davison, W. C., Duodenal contents of infants in health and during and following diarrhea. Am. J. Dis. Child., 1925, 29, 743.

10. Klumpp, T. G., and Neale, A. V., The gastric and duodenal contents of normal infants and children. Am. J. Dis. Child., 1930, 40, 1215.

11. Benoit, W., Hyperinsulinismus bei eingeborener Atresie des Pankreasganges. Endokrinologie, 1935, $16,313$.

12. Tiling, W., Angeborene Pankreasgangsatresie und Inselhypertrophie: Ein Beitrag zur Diagnostik der Pankreaserkrankungen. Arch. f. Kinderh., 1935, 106, 9.

13. Siwe, S. A., Ueber die exokrine Funktion des Pankreas und die Folgen ihres Wegfalles: Ein Fall von fast totaler Agenesie des exokrinen Teiles des Pankreas. Deutsches Arch. f. klin. Med., 1932, 173, 339.

14. Hanes, F. M., and McBryde, A., Identity of sprue, nontropical sprue and celiac disease. Arch. Int. Med., 1936, 58, 1.

15. Shohl, A. T., May, C. D., and Shwachman, H., Studies of nitrogen and fat metabolism on infants and children with pancreatic fibrosis. J. Pediat., 1943, 23, 267.

16. Farber, S., Experimental production of the lesion of achylia pancreatica. Am. J. Dis. Child., 1942, 64, 953. 